This immediately suggests the following construction :-

Take $O G=C$, and with this as radius, describe a semicircle. Draw any radius $O A$, then take $A B$ perpendicular to $O Y$, and $B P$ perpendicular to $O A$. then $P$ is a point on the required curve. Because

$$
\begin{aligned}
O B & =O A \cdot \cos O A B \\
& =O A \sin \theta, \quad \text { where } \theta=\text { angle } A O X .
\end{aligned}
$$

Also $O P=O B \sin \theta$

$$
=O A \sin ^{2} \theta \text {. }
$$

Therefore $P$ is a point on the curve.
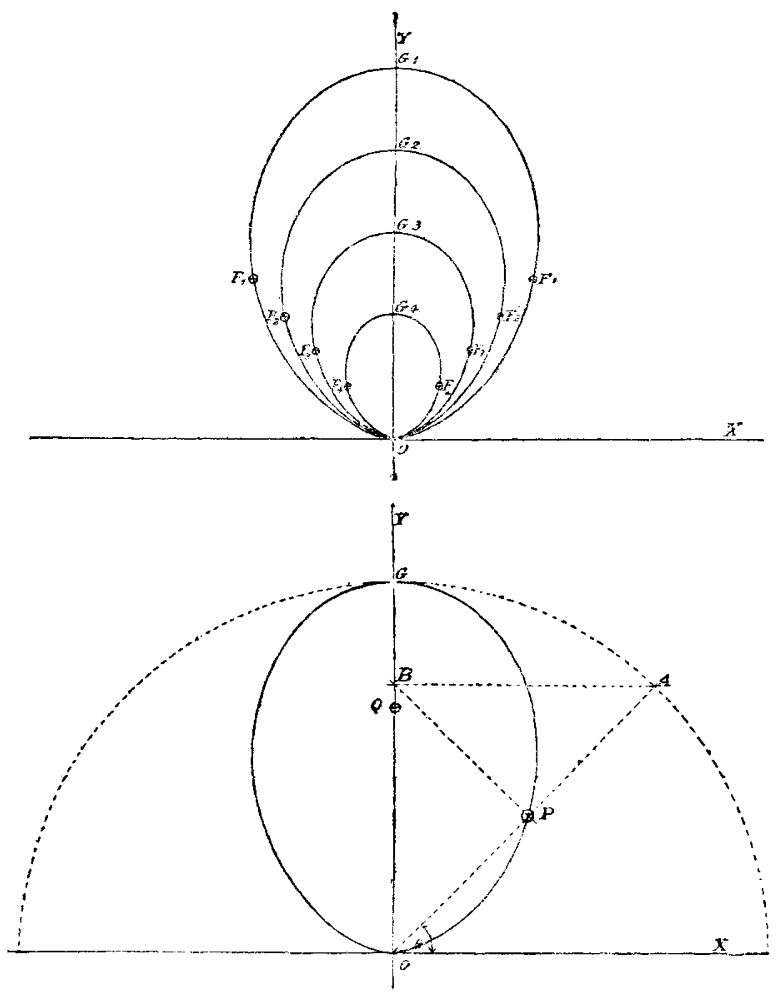

In a similar manner any number of foints on the curve may be obtained; and by varying the length $O G$, we get different curves of the same class.

Near to the point $G$ in the figure, the points on the curve cannot be constructed accurately by the method just given; but if the radius of curvature for the point $(x=0)$ be calculated, it will be found that for the point $G$ it is $\frac{O G}{3}, Q$ is the centre of curvature. And a large arc of the circle describec about $Q$ with radius $Q G$ coincides with the curve. Thus the whole curve may be constructed with great accuracy.

From equation (I) radius of curvature at any roint $\left(x^{\prime}\right)$ is given by

$$
\rho=\frac{C \cdot y\left(4 x^{2}+y^{2}\right)^{\frac{3}{2}}}{3\left(2 x^{2}+y^{2}\right)\left(x^{2}+y^{2}\right)}
$$

or, with $x$ eliminated by (I),

$$
\rho=\frac{C^{\frac{1}{3}} \cdot y^{\frac{1}{3}} \cdot\left(4 C^{\frac{2}{3}}-3 y^{\frac{2}{3}}\right)^{\frac{3}{2}}}{3\left(2 C^{\frac{2}{3}}-y^{\frac{2}{3}}\right)}
$$

Thus $y={ }^{-4} 432$ gives the point of maximum radius of curvature.

Lines of force-

$$
\frac{y^{2}}{\left(x^{2}+y^{2}\right)^{\frac{3}{2}}}=\frac{\mathrm{I}}{C} \text {. }
$$

These curves may be obtained by giving to $C$ the values

$$
\begin{aligned}
& C=O G_{1}, \\
& C \equiv O G_{2}, \\
& C=O G_{3}, \\
& C=O G_{4} .
\end{aligned}
$$

The points $(F)$ are points of minimum curvature.

Glasgow, January 29
Prehistoric Man in Japan

IN an article on this subject (NATURE, vol. xxi. p. 350) by Mr. F. V. Dickins, there is a mistake in dates. He says : "The 'adzuma' or eastern region of the main island was probably peopled chiefly by an Aino race, up to the fourteenth or fifteenth centuries." He hesitates to assign a higher antiquity to the Omori heaps (which were discovered by Prof. Morse) than the thirteenth or fourteenth century, and yet thinks it probable that they were the works of an Aino race. But the fact is that this part of the island was already inhalited by the present race, who had expelled the Ainos long before those periods. Consequently if, as he thinks, the heaps were the remains of the thirteenth or fourteenth century, they cannot be the works of the Ainos; if, on the other hand, they were the works of the Ainos, a much higher antiquity ought to be assigned to them. Such being the case, either one of his conclusions must be incorrect.

London

S. SUgIURA

\section{iNonkeys in the West Indies}

In Nature, vol. xxi, p. 131, there is a letter from Mr. Edmund Watt, of Dominica, calling in question the correctness of Prof. Mivart's statement in his paper on "Tails," regarding the non-existence of monkeys in the $\mathrm{W}$ est Indies.

If by this statement Prof. Mivart means that monkeys are not to be found wild at the present time in any of the West India islands, it is certainly incorrect, as they abound in St. Christopher and Nevis.

If, on the contraty, and what is much more probable, he means that monkeys are not native in any of these islands, then he has made no mistake, as I think I shall be able to show.

It certainly does appear remarkable that no srecies of monkey should exist in the wild state in any of these islands along the whole range from Grenada to Jamaica, with the exception of St. Christopher and Nevis, and the question that naturally presents itself is, Have they been introdnced? I am not aware that there is any tradition to this effect in either of these colonies.

It appeared to me that the most likely mode of obtaining in. formation on this point would be to examine all the old West India histories in my possession, as those writers who treated of the natural history of the islands could not fail to notice so singular a fact as the existence of monk eys in two neighbouring islands and in none of the others. The first history examined was that of Rochefort, "Histoire Naturelle et Morale des Antilles, I665." He names and describes all the mammalia in the West Indies known to him, but no mention whatever is made of monkeys. The next work examined was the "Histoire Générale des Antilles," by Père Du Tertre, 1667, a most interesting book, but little known. Du Tertre was a man of keen observation, and he has devoted a large portion of his work to natural history. He gives a very clear description of all the mammalia with which he was acquainted, but there is not a word about monkeys. This is the more notable from the fact that St. Cbristopher was considered the mother colony of the cther French settlements, and Du Tertre lived there for several years, and visited the island frequently. From the negative evidence afforded by Rochefort and Du Tertre, it may be concluded that monkeys did not then exist in these islands, and, in consequence, must have been subsequently introduced.

On examining a third historical work on the West Indies, that of Père Labat, "Nouveau Voyage aux Antilles, 1744," conclusive evidence was discovered of the zohen and the how of the importation of the monkey family into St. Christopher.

Father Labat says that he paid a visit to St. Christopher in the year I 700. He describes the French quarter, the island being inhabited at the time by French and English, and gives a very amusing account of a monkey hunt (chasse des singrs). He makes the following statement regarding the introduction of monkeys into the island, which I give in the original. "Pendant que les Anglais étoient demeurez maîtres des terres des Francois, dont la plus grande partie resterent en friche, les singes qui s'étoient échapez des maisons des Francois pendant la guerre, multiplierent tellement que quand on reprit possession de l'Isle cn les voyoit par grosses troupes. Ils venoient voler jusques dans les maisons, \& lorsqu'on plantoit des cannes, des patates ou autres choses, il falloit y faire sentinelle jour and nuit, si on vouloit que ces animaux n'emportassent pas tout ce qu'on avoit mis en terre."

It is thus made clear that the existence of monkeys in St. 